\title{
KONTRIBUSI HIDROLOGI KARST DALAM PENGELOLAAN KAWASAN KARST
}

\author{
Oleh : \\ TJAHYO NUGROHO ADJI \\ Kelompok Studi Karst Fakultas Geografi UGM (email : adji_tjahyo@ugm.ac.id)
}

\begin{abstract}
ABSTRAK
Hidrologi karst merupakan salah satu fokus riset di kawasan karst yang bernilai strategis karena keberadaan air sebagai obyek utamanya merupakan sumberdaya alam terpenting untuk kelangsungan makhluk hidup di kawasan ini baik permukaan maupun bawah permukaan. Selain itu, masalah penyediaan air di kawasan karst juga menjadi masalah klasik yang sampai saat ini pemecahannya masih sulit dilaksanakan, khususnya di Indonesia. Hanya saja, riset tentang hidrologi karst di Indonesia masih sangat terbatas dan belum mempunyai manfaat dalam pengelolaan ekosistem karst. Tulisan ini akan menyampaikan parameterparameter dalam hidrologi karst yang dapat digunakan sebagai indikator kerusakan maupun penegllaan lingkungan karst. Paper ini juga akan mengetengahkan metode-metode survey, peralatan yang digunakan, serta pendekatan-pendekatan untuk memonitor kondisi hidrologi bawah tanah daerah karst. Contoh-contoh pada tulisan ini merupakan data yang penulis peroleh sebagai bagian dari riset hidrologi karst secara temporal dan spasial yang sedang dilakukan di Daerah Tangkapan Air Sungai Bawah Tanah Bribin, Gunung Sewu, DIY
\end{abstract}

\section{Kata kunci : karst, hidrologi}

\section{Pendahuluan}

Kondisi hidrologi di daerah karst mempunyai karakteristik yang sangat berbeda jika dibandingkan dengan kondisi hidrologi di daerah non-karst. Perbedaan utamanya adalah terdapatnya perkembangan sungai bawah permukaan yang jauh lebih dominan daripada berkembangnya sungai permukaan. Hal ini terjadi karena proses geomorfologi yang mengontrol pembentukan karst adalah proses pelarutan (White, 1993). Selanjutnya, oleh Gillieson (1996), lorong-lorong bawah permukaan dan sungai bawah tanah ini disebut sebagai porositas lorong atau secara hidrogeologis dikenal sebagai porositas sekunder. Selanjutnya, perbedaan antara porositas batuan di daerah karst dan di daerah non-karst (sebagi contoh: lereng Merapi), disajikan pada Gambar 1. Jika kita cermati Gambar 1, maka akan terlihat bahwa porositas pada daerah non-karst (kiri) dapat dikatakan seragam ke segala arah, sehingga air akan mudah ditemukan di segala tempat. Sementara itu, porositas di daerah karst (kanan) sangat tergantung pada arah pembentukan lorong. Lorong-lorong tersebut yang kemudian jika terisi air akan membentuk sungai bawah tanah yang keberadaannya tidak terdistribusi merata ke segala arah (anisotropik).

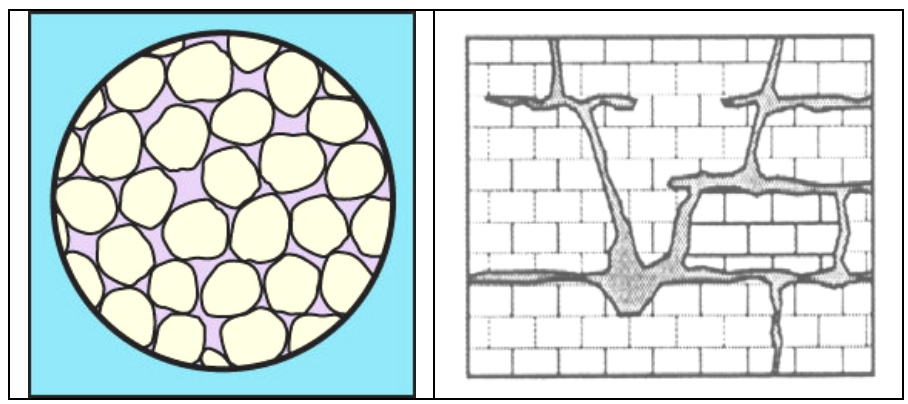

Gambar 1. Perbedaan porositas di daerah nonkarst (kiri), dan karst (kanan)

Karena sifatnya yang demikian, maka penduduk di daerah karst pada umumnya terkesan kesulitan untuk menemukan sumber air untuk mencukupi kehidupan mereka sehari-hari, padahal di bawah mereka sebenarnya terdapat sungai bawah tanah yang kadang kala debitnya bisa mencapai ribuan liter/detik. Lalu sebenarnya, bagaimanakah proses atau komponen aliran di 
daerah karst itu membentuk suatu siklus hidrologi, dan apakah siklus tersebut sama dengan siklus air yang terjadi di tempat lain?
White (2004) kemudian menjelaskan bahwa sebenarnya proses komponen aliran masukan dan keluaran air di daerah karst adalah seperti yang disajikan pada Gambar

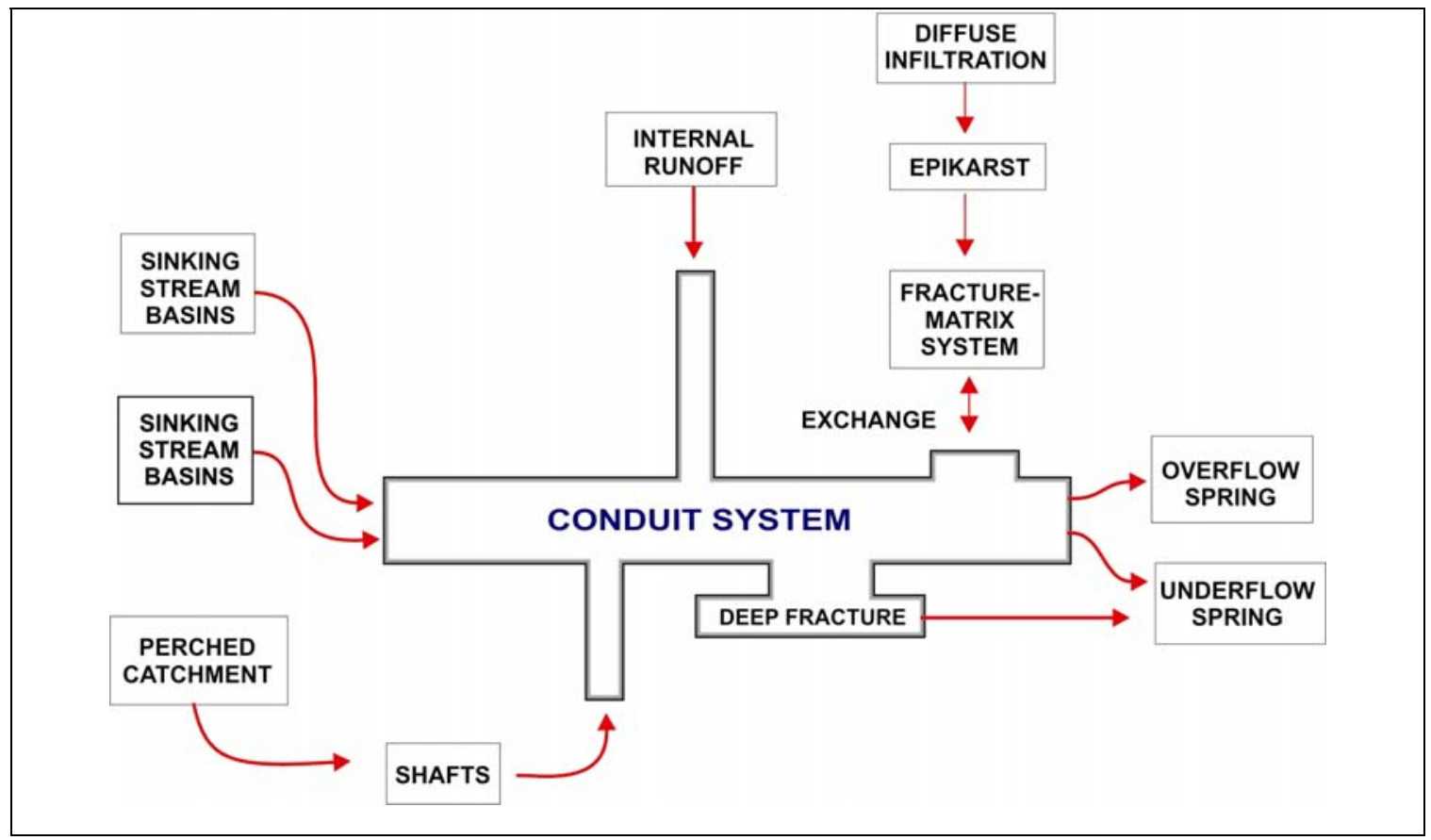

Gambar 2. Model konseptual sistem aliran airtanah pada akuifer karst (White, 2004)

Dari Gambar 2 dapat dijelaskan bahwa secara garis besar komponen aliran utama yang terdapat pada daerah karst adalah:

- Allogenic Recharge : yaitu aliran permukaan berupa sungai dari luar daerah karst yang masuk ke akuifer karst melalui ponor (swallow hole) pada basin karst

- Internal runoff : yaitu aliran permukaan dan hujan yang jatuh ke suatu cekungan karst tertutup dan kemudian masuk ke akuifer karst melalui sinkhole atau ponor pada suatu basin karst

- Diffuse infiltration : yaitu air hujan yang jatuh ke permukaan tanah dan kemudian terinfiltrasi secara perlahanlahan melalui pori-pori tanah dan kemudian dapat tersimpan dalam kurun waktu mingguan pada zone epikarst sebelum kemudian turun kebawah melalui rekahan atau matriks batuan menuju ke sungai bawah tanah.

- Imbuhan dari akuifer yang bertengger (perched aquifer) : yaitu imbuhan yang berasal dari akuifer lokal yang berada di atas akuifer karst yang kemudian dapat mencapai muka airtanah karst secara perlahan-lahan melaui sistem rekahan yang tersedia.

Sebelumnya, White (1988), Ford and Williams (1992), Smart and Hobbes (1986) serta Gillieson (1996) secara prinsip membagi sifat dan jenis komponen aliran di karst menjadi sifat aliran saluran/lorong (conduit), celah (fissure), dan rembesan (diffuse). Selanjutnya, untuk lebih sederhana, oleh Domenico and Schwartz (1990) sifat komponen aliran di karst dibagi menjadi dua komponen aliran yang mempunyai perbedaan yang tegas yaitu (1) komponen aliran diffuse dan (2) komponen aliran conduit, seperti yang diilustrasikan pada Gambar 3. 


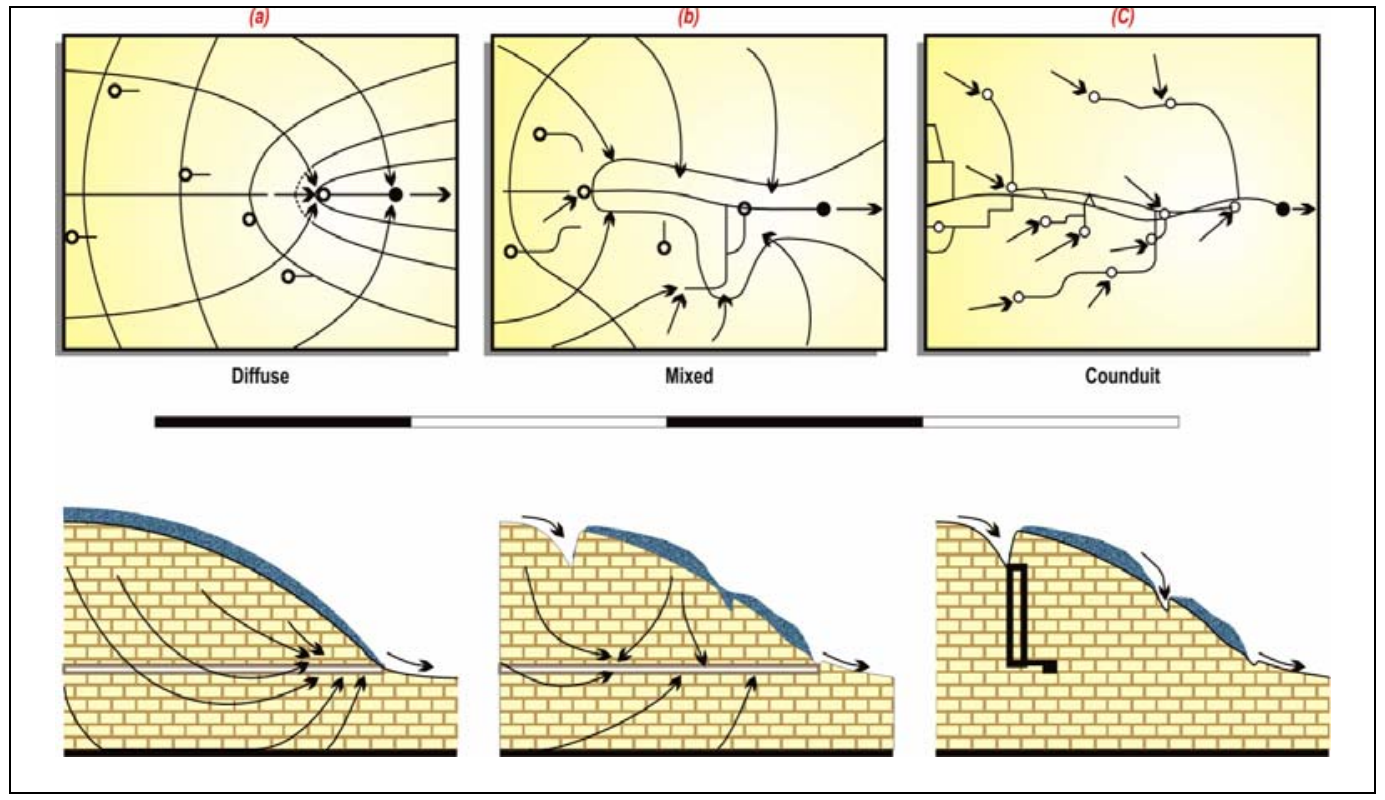

Gambar 3. Komponen aliran diffuse, campuran dan conduit (Domenico and Schwartz, 1990)

Komponen aliran diffuse adalah komponen aliran yang masuk ke sungai bawah tanah melalui proses infiltrasi yang terjadi secara perlahan-lahan melewati zone permukaan bukit karst (epikarst) dan kemudian mengimbuh sungai bawah tanah berupa tetesan ataupun rembesan-rembesan kecil. Contoh yang paling sering kita lihat adalah tetesan pada ornamen gua. Sementara itu, conduit adalah komponen aliran yang mengimbuh sungai bawah permukaan melalui ponor yang ada dipermukaan, dan melewati rongga-rongga yang besar dengan kecepatan aliran yang cepat dan akan menghasilkan banjir pada sungai bawah tanah jika imbuhan hujan di permukaan besar. Contoh komponen aliran ini yang paling ekstrim adalah jika kita terkena banjir saat di dalam gua. Dominasi salah satu jenis komponen aliran pada suatu daerah karst terutama tergantung dari tingkat perkembangan karst (stadium muda, dewasa, maupun tua). Jika karst sudah memasuki stadium tua dengan sistem pelorongan sudah berkembang baik, maka komponen aliran conduitlah yang lebih dominan. Faktor lain adalah kerusakan permukaan karst karena aktivitas manusia.

\section{Bagaimana ciri-ciri potensi air karst yang masih mungkin bertahan dalam jangka panjang?}

Banyak faktor yang dapat dijadikan indikator untuk menjawab pertanyaan ini. Tentu saja kita akan berpikir bahwa potensi sungai bawah tanah dapat dibilang baik adalah jika air masih tersedia cukup banyak di saat puncak musim kemarau. Hal ini memang benar, atau dalam kalimat lain dapat dikatakan bahwa jika keberadaan komponen diffuse flow masih cukup untuk mengisi sungai bawah tanah pada saat kemarau puncak, maka potensi sungai bawah tanah masih aman. Tetapi, apakah cukup hanya dengan mengetahui hal ini kita sudah dapat menyimpulkan bahwa potensi sungai bawah tanahnya aman untuk jangka waktu yang panjang ke depan?? Lalu bagaimanakah dengan keberadaan conduit flow? Berapakah sebenarnya rasio atau perbandingan antara diffuse flow versus conduit flow pada sungai bawah tanah pada suatu waktu tertentu, lalu apakah prosentase diffuse flow meningkat atau menurun dari tahun ke tahun? Hal inilah yang harus selalu dimonitor dan dicermati secara seksama untuk menyimpulkan proses dan keberlangsungan sungai bawah tanah. Jika dari tahun ke tahun prosentase diffuse flow mempunyai kecenderungan (trend) yang menurun, maka terjadilah degradasi atau penurunan potensi sungai bawah tanah, dan inilah yang harus diwaspadai. 
Hal lain yang dapat mencirikan baik tidaknya potensi sungai bawah tanah adalah respon debit sungai terhadap hujan. Jika suatu sungai bawah tanah atau mata air mempunyai respon yang sangat cepat jika terjadi hujan, maka dapat disimpulkan bahwa komponen aliran didominasi oleh conduit. Ford and Williams (1992) mengungkapkan bahwa kondisi akuifer karst masih baik jika mataair karst mempunyai respon debit puncak sekitar $3-4$ bulan sesudah hujan puncak terjadi. Artinya bukitbukit atau topografi karst di permukaaan masih mampu menjadi regulator dan mengatuskannya secara perlahan-lahan ke mataair atau sungai bawah tanah.

Pertanyaan lain, faktor-faktor apa sajakah yang berpengaruh terhadap rasio prosentase komponen aliran pada suatu sungai bawah tanah?
Publikasi oleh Smart and Hobbes (1986) mengungkapkan bahwa dominasi komponen aliran sangat ditentukan oleh karakteristik perkembangan lorong-lorong karst, kondisi topografi permukaan, dan kondisi simpanan air didalam akuifer karst, yang ilustrasinya disajikan pada Tabel 1 dan Gambar 4. Tentu saja, seperti terlihat pada Gambar 4, maka kondisi imbuhan yang tidak terkonsentrasi, simpanan yang banyak serta dominasi tipe aliran diffuse merupakan potensi yang paling ideal yang menghasilkan bentuk hubungan antara debit dan waktu (hidrograf) seperti pada pojok kanan bawah pada Gambar 4.

Tabel 1. Karakteristik Aliran Akifer Karst

\begin{tabular}{|l|l|l|l|}
\hline Tipe aliran & \multicolumn{1}{|c|}{ Karakteristik } & Kondisi Daerah Tangkapan & \multicolumn{1}{c|}{ Simpanan } \\
\hline Conduit & $\begin{array}{l}\bullet \text { Perpipaan (streansink) } \\
\bullet \text { Sangat cepat dan sensitif } \\
\text { terhadap hujan }\end{array}$ & $\begin{array}{l}\bullet \text { Banyak luweng dengan sinkhole } \\
\text { dan ponor }\end{array}$ & $\begin{array}{l}\bullet \text { Rendah dan hanya pada } \\
\text { saat musim hujan }\end{array}$ \\
\hline Diffuse & $\begin{array}{l}\bullet \text { Menyebar } \\
\bullet \text { Respon lambat terhadap hujan }\end{array}$ & $\begin{array}{l}\bullet \text { Fracture } \\
\bullet \text { Intergranuler }\end{array}$ & $\bullet$ Besar dan sepanjang tahun \\
\hline
\end{tabular}

Sumber : Smart and Hobbes (1986)

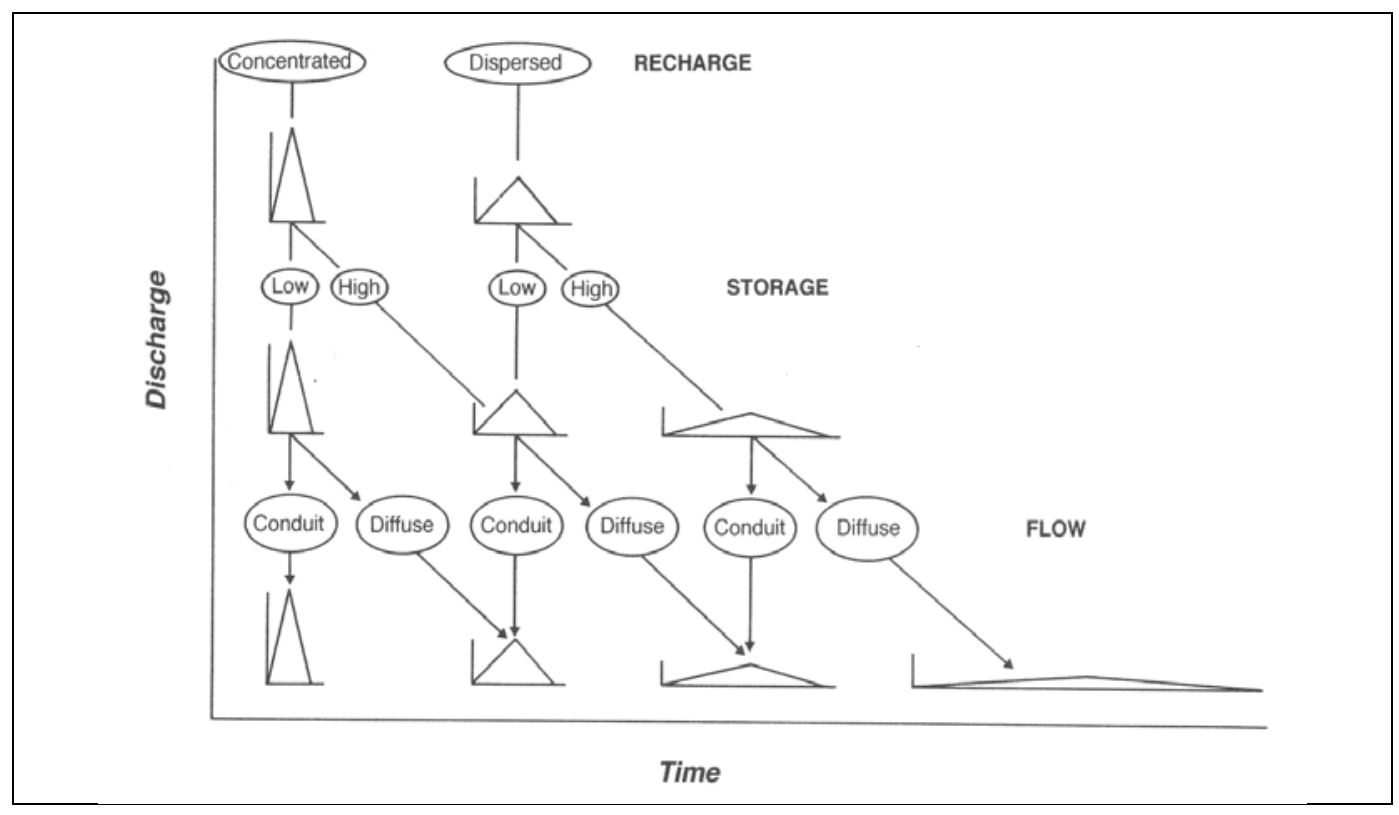

Gambar 4. Tiga sub-sistem bertingkat yang menghasilkan perbedaan hidrograf aliran pada mataair karst oleh Smart and Hobbes (1986) 
Bagaimana mengetahui dominasi salah satu jenis komponen aliran ?

Untuk mengenal tipe aliran dominan yang berkontribusi terhadap sungai bawah tanah serta responnya terhadap kejadian hujan, maka diperlukan suatu survey hidrologi yang diagram alirnya disajikan pada Gambar 5.

\section{Bagimana menentukan lokasi penelitian dan lokasi} alat-alat pengukuran?
Contoh yang digunakan pada tulisan in adalah kegiatan penelitian yang sedang dilakukan oleh penulis yang berlokasi di daerah tangkapan hujan sungai bawah tanah Bribin, Gunung Sewu, Kab. Gunung Kidul. Peta jaringan sungai Bribin huluhilir yang digunakan adalah peta hasil penelitian McDonald and Partners (1984) yang belum diperbaharui sampai saat ini, seperti yang ditunjukkan pada Gambar 6.

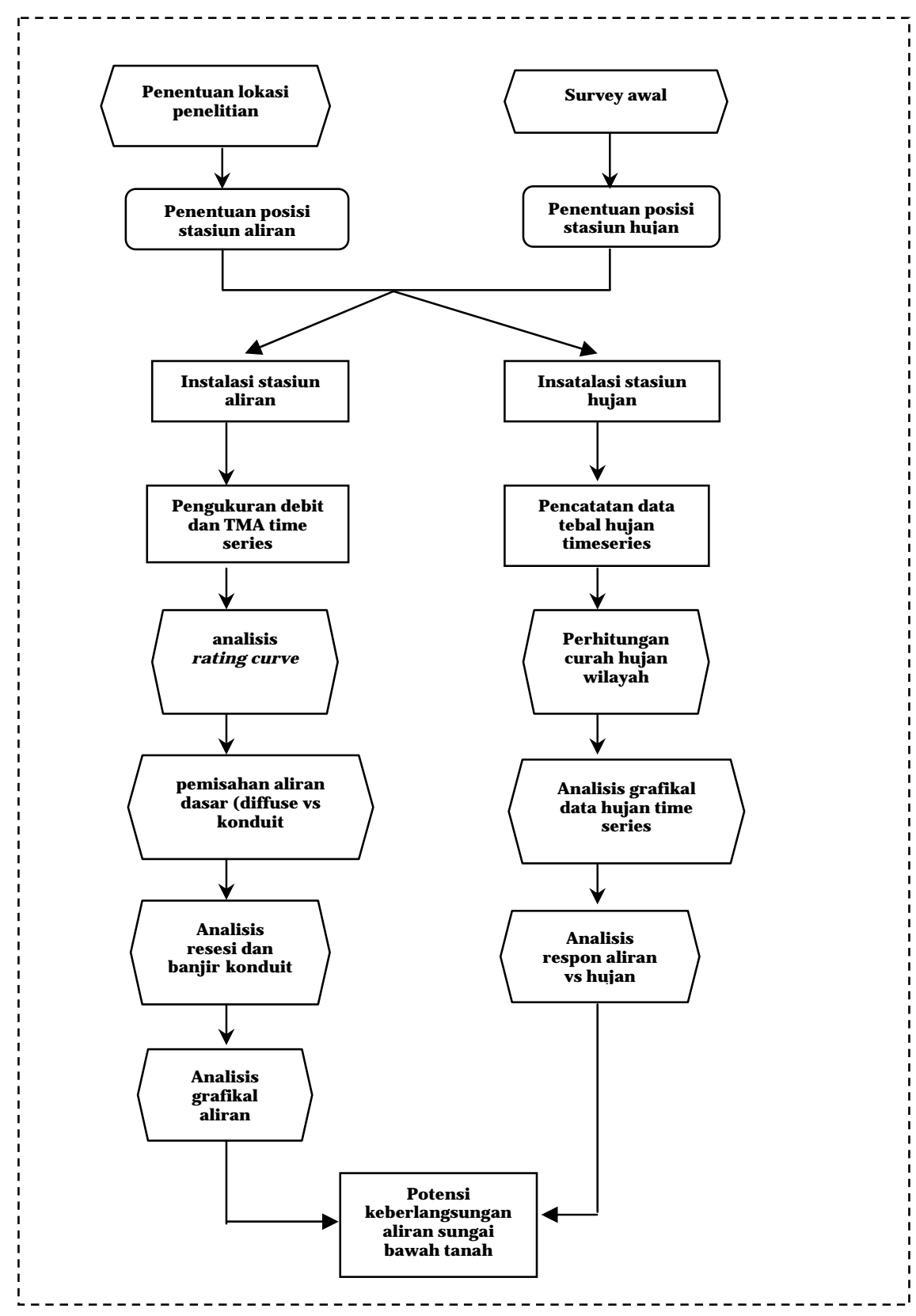

Gambar 5. Diagram alir monitoring keberlangsungan potensi sungai bawah tanah 


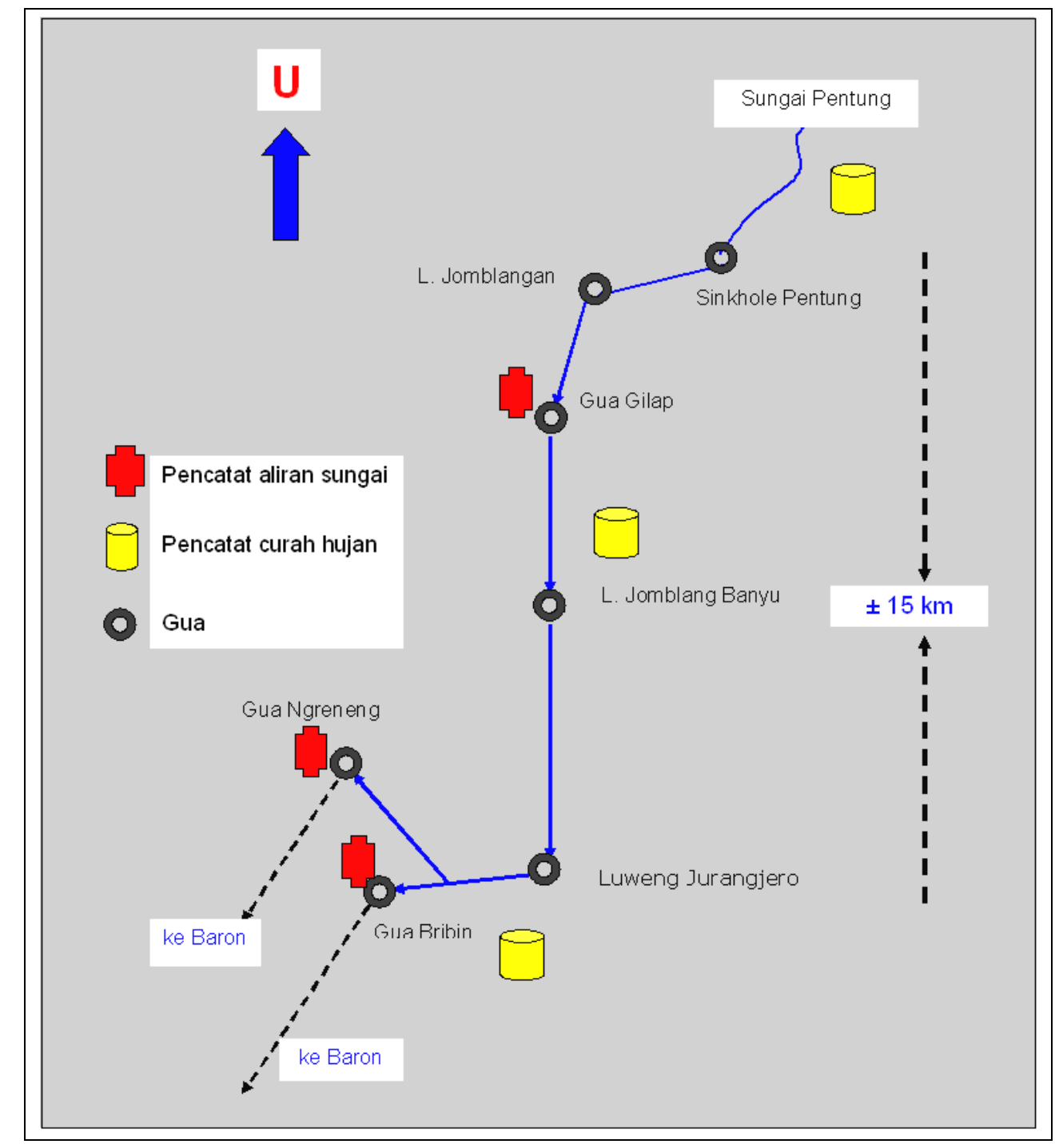

Gambar 6. Lokasi penelitian dan penempatan alat ukur

Selanjutnya, beberapa hal yang perlu diperhatikan dalam menentukan posisi alat pengukuran diantaranya adalah:

(a) Persebarannya untuk mewakili luasan tertentu. Sebagai contoh pada Gambar 6 terlihat bahwa 3 buah penakar hujan ditempatkan sedemikian rupa sehingga persebaran hujan di daerah hulu, tengah, dan hilir dapat terwakili.

(b) Kemudahan aksesibilitas. Pada Gambar 6, persebaran stasiun pencatat aliran sungai bawah tanah sepertinya tidak tersebar merata. Hal ini diakibatkan sulitnya memperoleh gua yang memiliki akses yang mudah untuk diamati pada waktuwaktu yang dikehendaki. Sebagai contoh, lokasi yang paling ideal secara spasial untuk penempatan stasium aliran adalah di Luweng Jomblang Banyu, tetapi mengingat aksesibilitas menuju sungai yang membutuhkan waktu diatas 12 jam menyebabkan lokasi ini tidak 
memungkinkan untuk dipasang stasiun aliran.

\section{Jenis peralatan utama pengukuran \\ hidrologi yang diperlukan}

a) Penakar hujan (rain gauge). Penelitian perilaku sungai bawah tanah mensyaratkan penakar hujan otomatis sehingga tidak perlu setiap hari mencatat secara manual. Beberapa tipe penakar hujan yang dipasang pada penelitian penulis adalah seperti yang disajikan pada Gambar 7. Sementara itu, data hujan yang dihasilkan sebagi contoh adalah seperti yang disajikan pada Gambar 8.
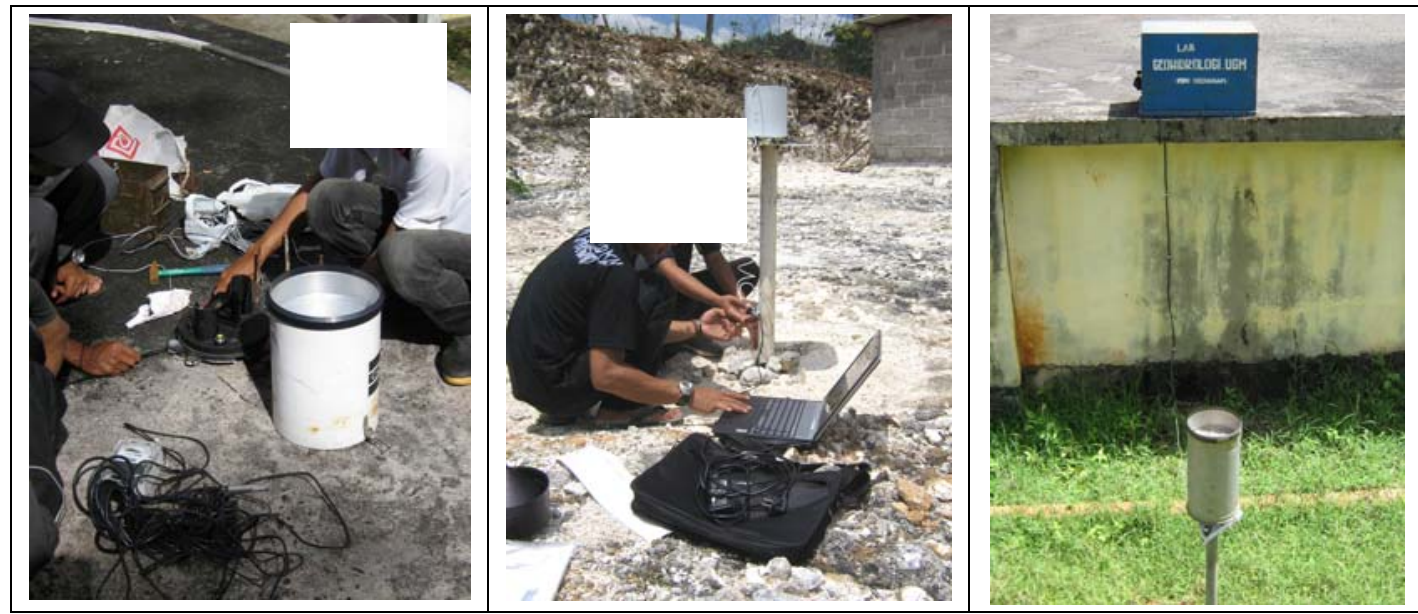

Gambar 7. Penakar hujan otomatik tipe Castella (hulu DAS Bribin-kiri); Onset-HOBO RG3M (tengah DAS Bribin-tengah); semi otomatik (hilir DAS Bribin-kanan)

Curah Hujan Hulu Bribin 28 Apr-23 Mei 2006

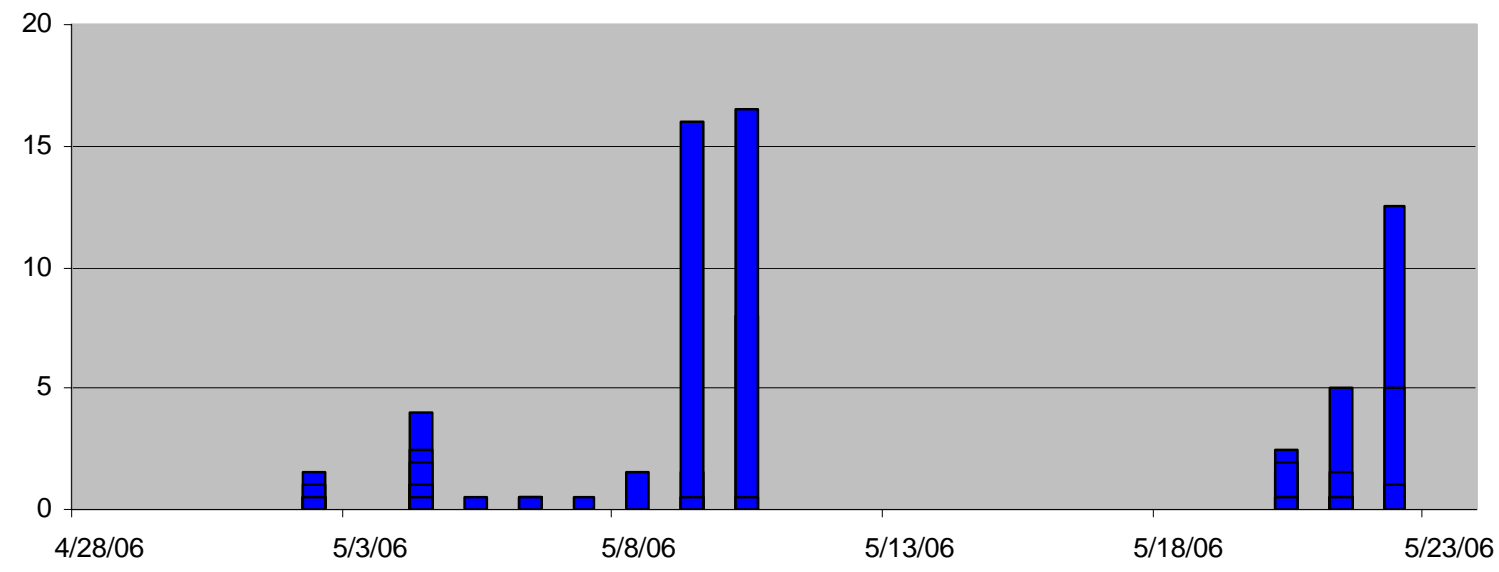

Gambar 8. Contoh data hujan yang dihasilkan dari penakar hujan yang dipasang di hulu Sungai Bribin (28 April-23 Mei 2006)

b) Alat pencatat tinggi muka air (water level data logger). Untuk mengetahui fluktuasi tinggi muka air secara time series, diperlukan instalasi stasiun aliran sekaligus pemasangan alat pencatat tinggi 
muka air, seperti yang disajikan pada aliran Gua Gilap disajikan pada Gambar Gambar 9, sementara contoh hasil 10. pencatatan tinggi muka air di stasiun
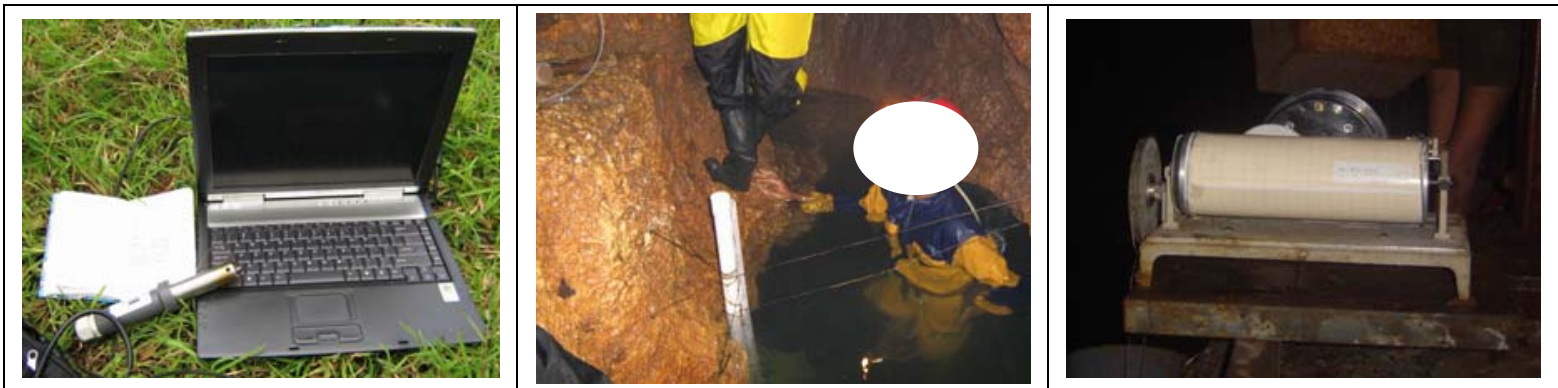

Gambar 9. Data Logger TMA yang dipasang di Gua Gilap (kiri); instalasi stasiun aliran di Gua Ngreneng (tengah); automatic water level recorder -AWLR di Gua Bribin (kanan).

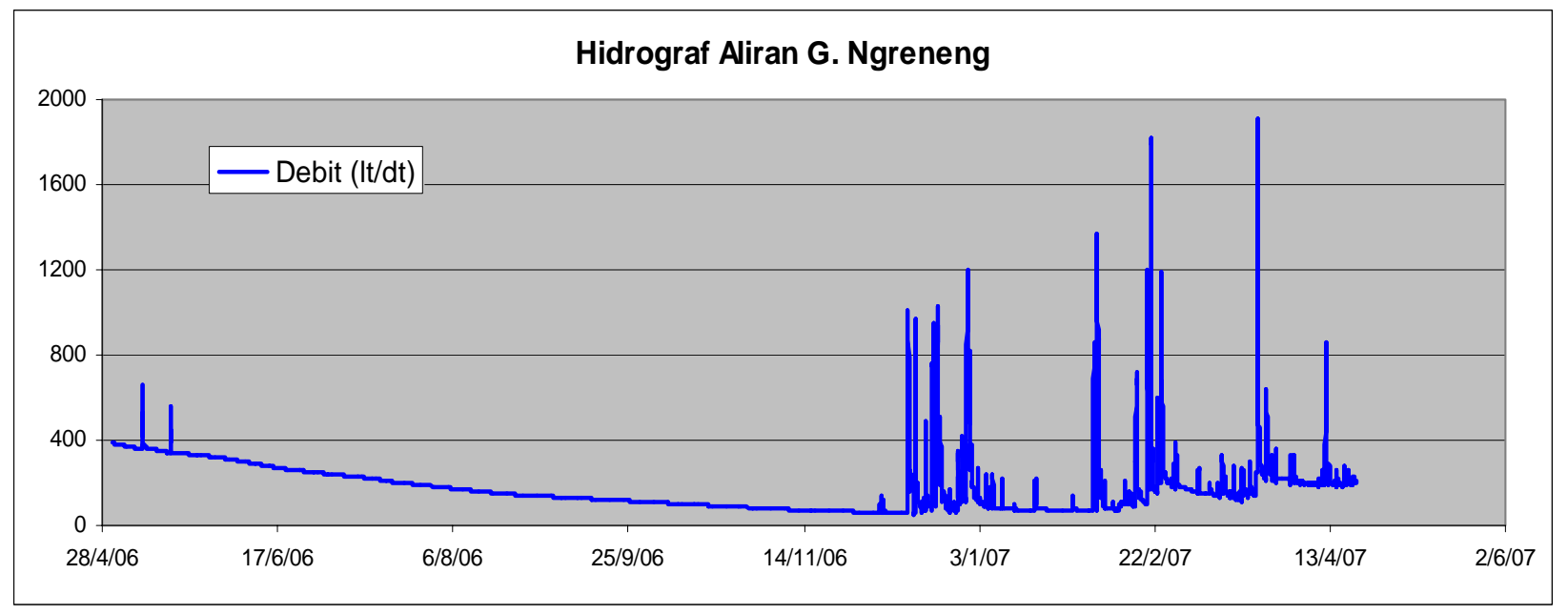

Gambar 10. Contoh data aliran di stasiun aliran Gua Ngreneng, Gunungkidul

c) Alat pengukur debit sungai bawah tanah. Beberapa metode yang dapat dilakukan untuk menghitung debit sungai bawah tanah diantaranya dalah metode volumetric, velocity area method, dan slopearea. Hanya saja dalam penelitian ini metode yang dipilih adalah metode velocity-area, yaitu dengan mengalikan kecepatan aliran dan luas penampang basahnya. Selanjutnya, kecepatan aliran dihitung dengan mengunakan alat current meter, yang ilustrasinya seperti yang disajikan pada Gambar 11. Prinsip kerja current meter adalah menghitung putaran baling-baling pada alat persatuan waktu tertentu (N), yang kemudian nilai tersebut dimasukkan dalam rumus kecepatan yang tertera pada alat, sehingga kecepatan arus pada titik yang dikehendaki dapat diketahui. Terakhir, nilai kecepatan arus dikalikan dengan luas penampang basah (air) sehingga akan diketahui debit aliran sungai bawah tanah. 


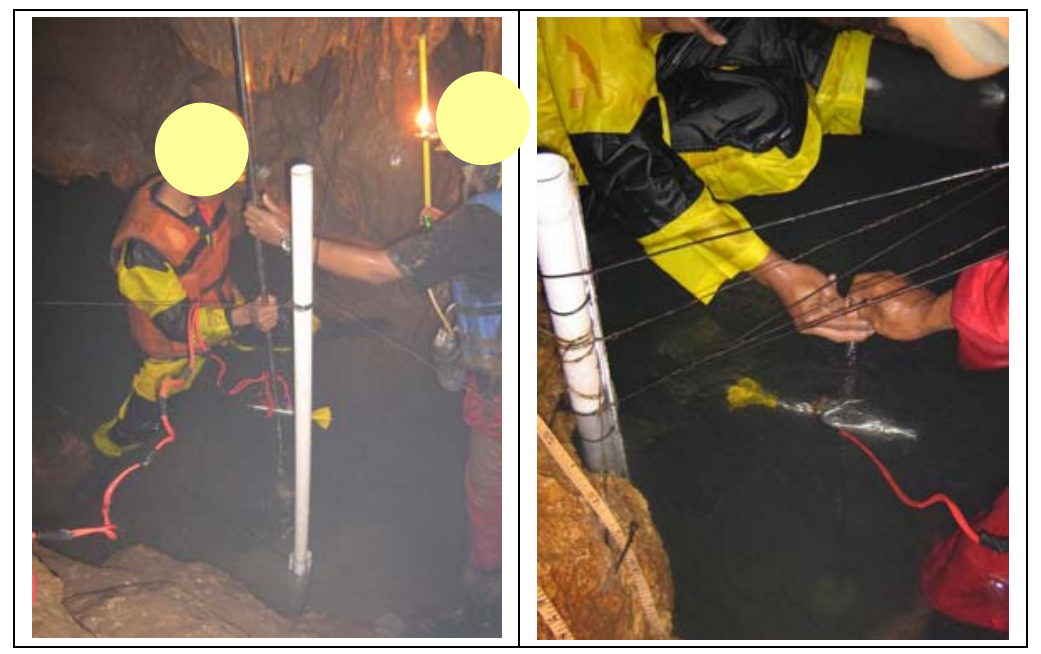

Gambar 11. Pengukuran debit aliran dengan current meter di Gua Gilap (kiri) dan Gua Ngreneng (kanan)

\section{Analisis stage discharge rating curve debit sungai bawah tanah}

Tentu saja, kita tidak mungkin setiap saat mengukur debit di lapangan. Selain membutuhkan waktu dan biaya yang tidak sedikit, juga resiko kebanjiran yang mungkin terjadi pada gua-gua yang didominasi oleh aliran tipe conduit. Atas dasar tersebut, maka perlu dilakukan pemodelan hubungan antara debit aliran dengan tinggi muka air sungai bawah tanah yang dikenal sebagai pengukuran debit tidak langsung dengan analisis korelasi dan regresi antara data TMA dan debit terukur pada saat tertentu yang mewakili debit puncak, menengah dan minimum untuk membuat rumus lengkung aliran atau stage discharge rating curve. Cara yang dipakai adalah cara sederhana yaitu regresi linier dengan jumlah sampel kecil (Schulz, 1976). Pada kesempatan ini penulis belum dapat membuat kurva lengkung aliran ini di lokasi penelitian, mengingat penelitian yang masih berlangsung dan belum mengukur debit aliran pada saat banjir. Contoh yang dikemukakan pada tulisan ini adalah rating curve yang dibuat oleh Suryanta (2001) di Sungai Bribin dengan data pengukuran seperti yang disajikan pada Tabel 2 . Dari data tersebut kemudian dicari persamaan regresi hubungan antara debit dan TMA seperti yang disajikan pada Gambar 12. 
Tabel 2. Tabel Hubungan Debit dan TMA Sungai Bribin

\begin{tabular}{|l|l|l|r|r|}
\hline No & Tanggal & Jam & TMA (m) & \multicolumn{1}{c|}{ Debit (It/dt) } \\
\hline 1 & 18 Jan 2000 & $11: 00$ & 0,98 & 1297,19 \\
\hline 2 & 28 Jan 2000 & $11: 45$ & 1,06 & 1277,65 \\
\hline 3 & 5 Feb 2000 & $12: 15$ & 1,61 & 1939,94 \\
\hline 4 & 20 Feb 2000 & $13: 00$ & 1,37 & 1605,24 \\
\hline 5 & 23 Feb 2000 & $13: 30$ & 1,27 & 1480,61 \\
\hline 6 & 4 Mar 2000 & $14: 00$ & 1,10 & 1346,78 \\
\hline 7 & 8 Mar 2000 & $14: 15$ & 0,8 & 1001,15 \\
\hline 8 & 13 Mar 2000 & $14: 15$ & 1,33 & 1571,08 \\
\hline 9 & 18 Mar 2000 & $12: 00$ & 0,8 & 923,67 \\
\hline 10 & 22 Mar 2000 & $16: 00$ & 0,97 & 1176,54 \\
\hline 11 & 27 Mar 2000 & $16: 30$ & 1,36 & 1732,06 \\
\hline 12 & 1 Apr 2000 & $11: 15$ & 0,86 & 1027,89 \\
\hline 13 & 10 Apr 2000 & $12: 15$ & 0,87 & 979,63 \\
\hline 14 & 25 Apr 2000 & $14: 00$ & 1,44 & 1743,91 \\
\hline 15 & 30 Apr 2000 & $13: 25$ & 0,94 & 1123,09 \\
\hline
\end{tabular}

Sumber : Suryanta (2001)

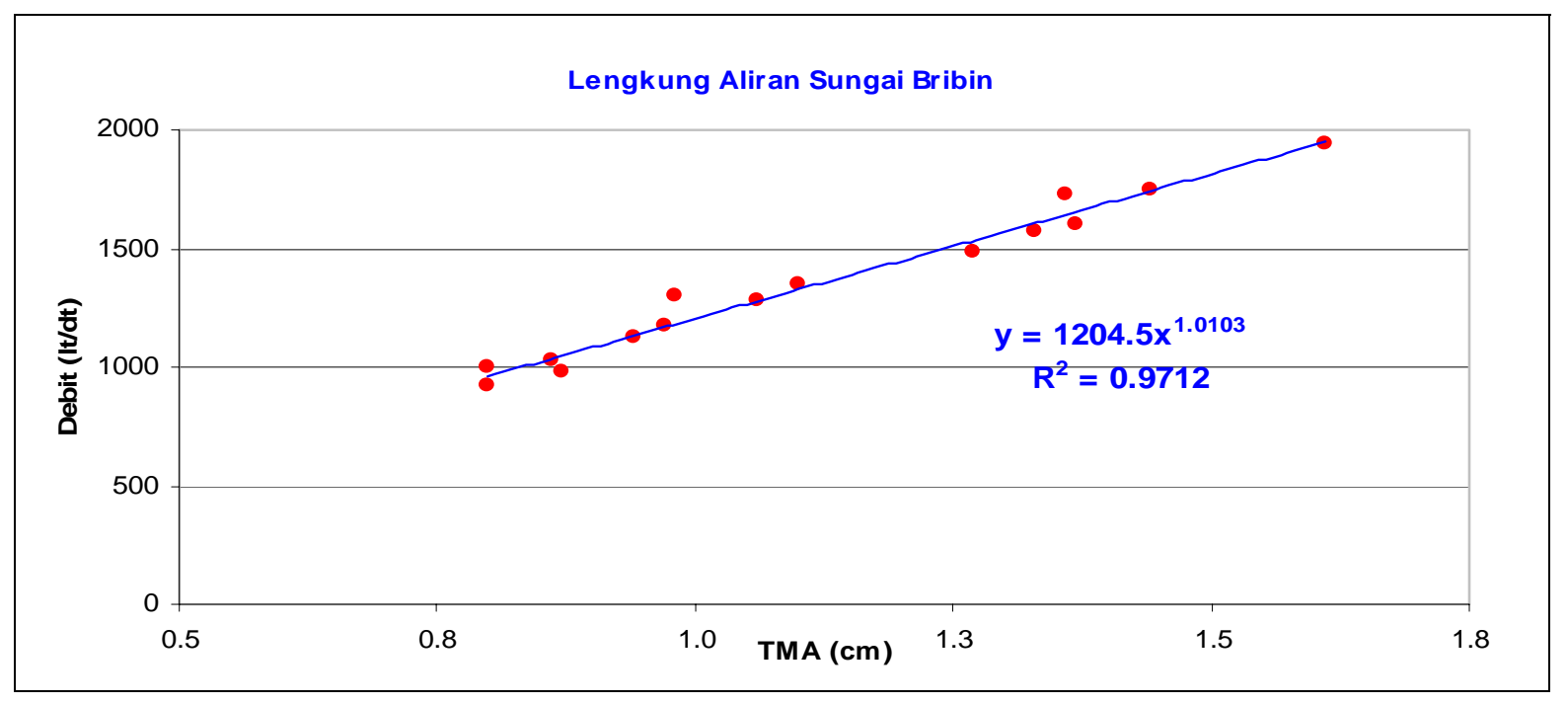

Gambar 12. Lengkung aliran (rating curve) Sungai Bribin (Suryanta, 2001)

Selanjutnya, kita tinggal mengukur TMA jika ingin mengetahui debit aliran sungai Bribin, dengan menggunakan persamaan $\mathbf{Q}=1204.5$ (TMA) ${ }^{1,0103}$, dimana TMA dalam satuan meter, dan $Q$ dalam satuan liter/detik.

Monitoring prosentase komponen aliran conduit vs diffuse secara time series
Jika kita sudah memiliki data debit vs waktu sepanjang tahun atau dikenal sebagai discharge hydrograph (Gambar 13), maka kita selanjutnya kita bisa memisahkan prosentase besaran komponen aliran diffuse dan conduit pada waktu-waktu tertentu. Seperti kita ketahui, sungai bawah tanah yang kondusif akan mempunyai komponen aliran diffuse 
yang berkesinambungan dengan prosentase dan debit yang stabil dari tahun ke tahun.

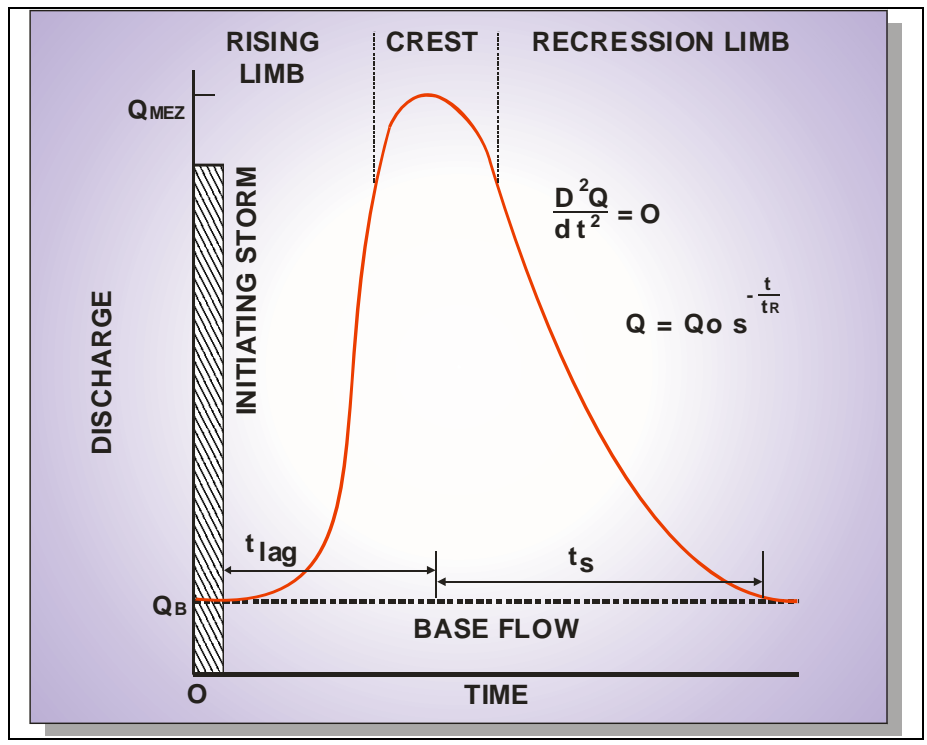

Gambar 13. Hidrograf sungai bawah tanah karst pada satu kali kejadian hujan (White, 1993)

Selanjutnya, untuk memisahkan komponen aliran diffuse dan conduit ini dapat dilakukan analisis base flow separation dan perhitungan aliran langsung sepanjang tahun (Gambar 14), sementara metode pemisahan aliran dasar yang paling sederhana menggunakan straight line method (Schulz, 1976). Dari Gambar 14 terlihat bahwa garis warna merah merupakan besaran base flow di daerah karst yaitu komponen aliran diffuse.

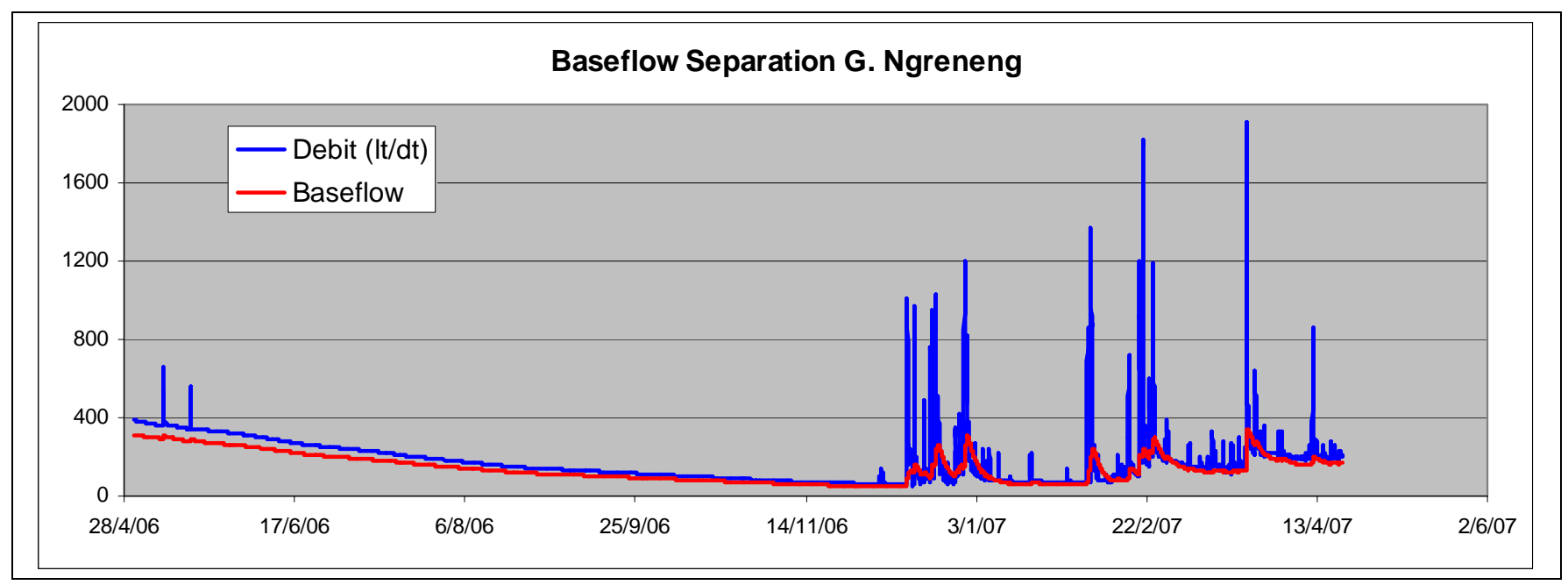

Gambar 14. Pemisahan aliran dasar dengan metode digital filtering di Gua Ngreneng, Gunungkidul

Selanjutnya, untuk mengetahui karakteristik diffuse flow, bisa dilakukan juga analisis lengkung resesi atau besarnya pelepasan diffuse flow dari akuifer karst, yang contohnya setelah dianalisis kemudian disajikan pada Gambar 15. 


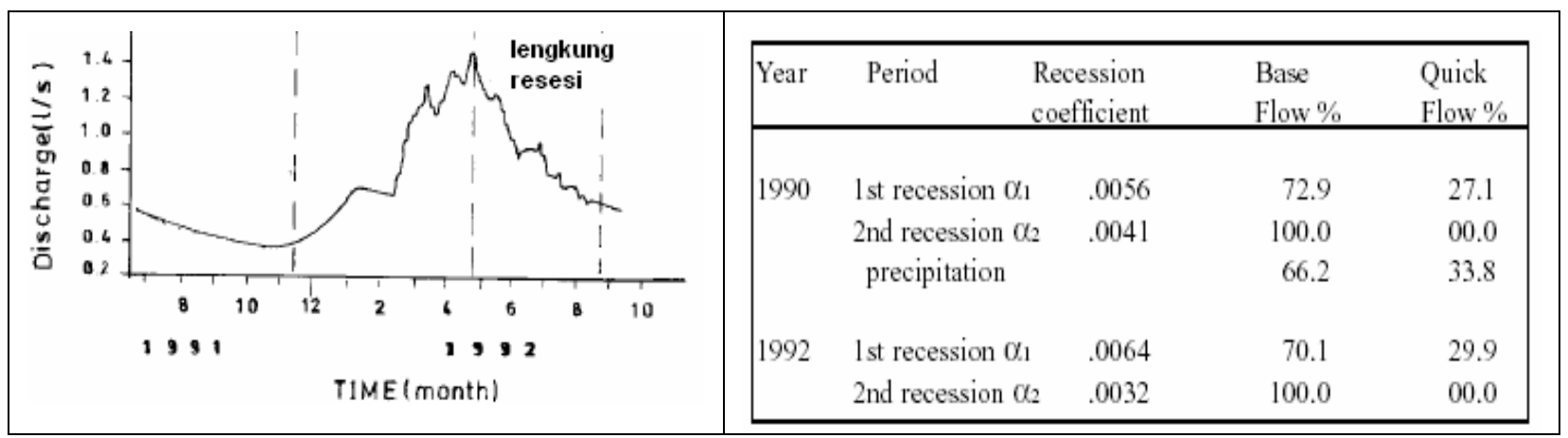

Gambar 15. Analisis resesi diffuse flow (Raeisi dan Karami, 1997)

Kemudian, jika perhitungan prosentase diffuse flow dan koefisien resesi dilakukan pada waktu yang panjang, maka sifat keberlangsungan sungai bawah tanah dapat dievaluasi.

\section{Respon sungai bawah tanah terhadap hujan}

Analisis ini juga bisa dilakukan untuk mengetahui dominasi komponen aliran pada suatu sungai bawah tanah. Sungai bawah tanah yang mempunyai dominasi diffuse flow yang baik, akan mempunyai respon debit puncak (time lag) tidak seketika merespon hujan sesaat. Dengan kata lain, pada kondisi ini conduit flow tidak dominan, dan debit aliran mantap (diffuse flow) masih tersedia dengan baik. Kemudian, contoh hubungan hujan dan kondisi aliran pada daerah penelitian penulis bulan April s.d Mei 2006 disajikan pada Gambar 16.

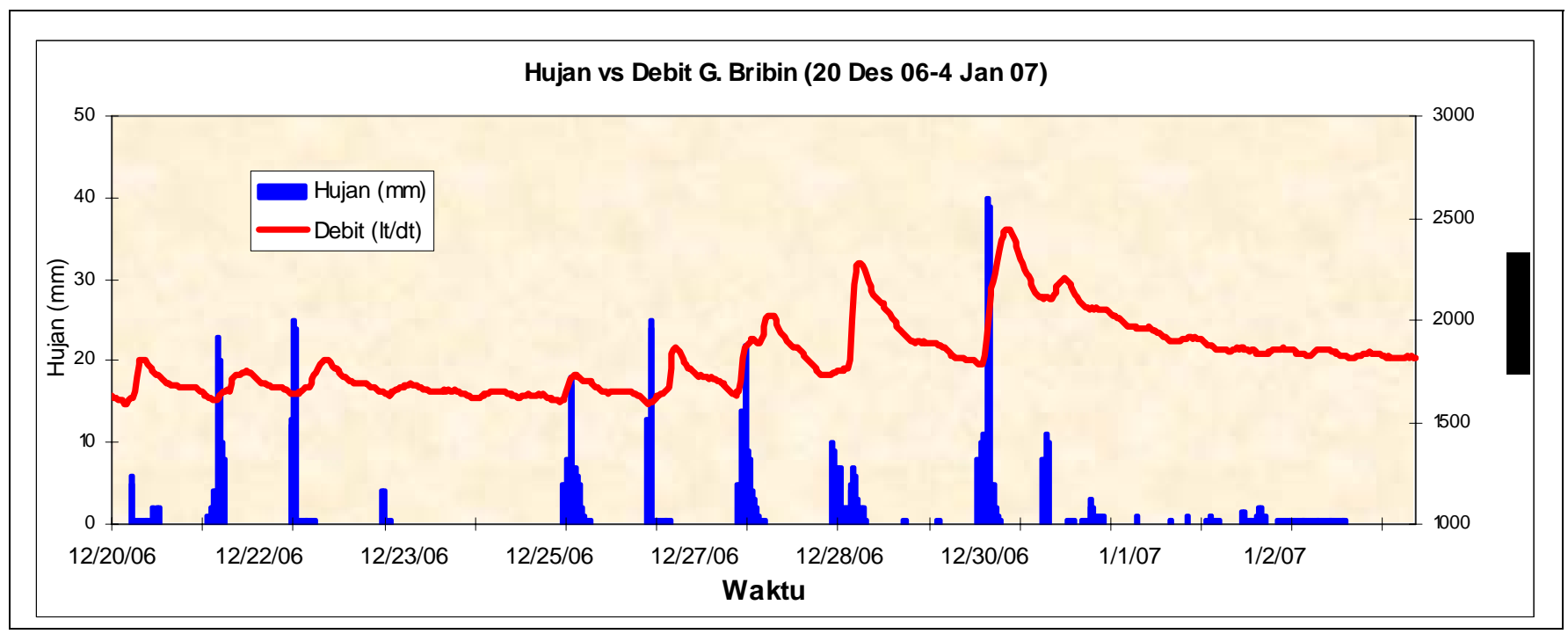

Gambar 16. Respon Sungai Bawah Tanah Bribin terhadap Hujan

Ternyata, kenaikan hujan sebesar kurang dari 10 mm/jam langsung direspon pada kenaikan debit di Sungai Bribin, sehingga dapat disimpulkan bahwa banyak lobang ponor dan adanya dominasi konduit pada daerah tangkapan Sungai Bribin.
Sampai saat ini, proses pengukuran dan pencatatan hubungan ini masih dilakukan oleh penulis.

Penutup

Demikianlah telah dikemukakan faktor-faktor yang dapat dijadikan indikator untuk memonitor 
keberlangsungan sungai bawah tanah. Inti dari tulisan ini adalah bagaimana cara mempertahankan keberadaan diffuse flow sehingga tetap konsisten mengimbuh sungai bawah tanah. Perlu pula diingat bahwa faktor manusia dapat mengurangi atau merubah distribusi diffuse flow pada sungai bawah tanah. Sebagai contoh adalah penambangan bukit karst yang akan secara signifikan mengurangi imbuhan diffuse flow ke sungai bawah tanah. Selain itu, tanpa diffuse flow keberlangsungan ekosistem bawah tanah, khususnya biota gua akan terganggu dan bahkan mati, lebihlebih pada musim kemarau. Disinilah sebenarnya peranan hidrologi karst dalam menunjang kehidupan ekosistem dan makhluk hidup yang tinggal di dalamnya.

\section{Referensi}

Domenico,P.A. and Schwartz, F.W., 1990, Physical and Chemical Hydrogeology. $2^{\text {nd }}$ Ed. John Wiley \& Sons

Ford, D. and Williams, P. 1992. Karst Geomorphology and Hydrology, Chapman and Hall, London
Gillieson, D., 1996, Caves: Processes, Development, and Management, Blackwell, Oxford

Ininternet :

:http://www.usbr.gov/pmts/hydraulics_lab/twahl/bfi/co mal.gif

MacDonalds and Partners. 1984. Greater Yogyakarta Groundwater Resources Study. Vol 1: Main Report. Yogyakarta, Directorate General of Water Resources Development Project (P2AT)

Raeisi,R., Karami,G., 1997. Hydrochemographs of Berghan karst spring as indicators of aquifer characteristics, Journal of Cave and Karst Studies 59(3), $112-118$

Schulz, E.F., 1976. Problems in Applied Hydrology. Water Resources Publication, Colorado

Suryanta, G., 2001, Kajian Karakteristik Hidrograf Satuan Daerah Karst Gunung Kidul (Studi Kasus: Daerah Tangkapan Air Sungai Bawahtanah Bribin, Kabupaten Gunung Kidul, Propinsi DIY), Skripsi Sarjana, Fakultas Geografi, UGM, Yogyakarta

White, W.B., 1988. Geomorphology and Hydrology of Karst Terrain. Oxford University Press, New York

White, W.B., 1993. Analysis of Karst Aquifer. In:Alley, W.M. (editor), regional groundwater Quality. Van Nostrand Reinhold, New York

White, W.B., 2004. Conceptual Models for Karstic Aquifers, www.speleogenesis.info 